\title{
A New Field Protocol for Determination of Forest Structure, Biodiversity and Heath Status by Means of GPS Tools: A Case Study from Gaza Forest
}

\author{
Yasser El-Nahhal \\ Department of Environmental and Earth Sciences, Faculty of Science, The Islamic University of Gaza, Gaza, Palestine \\ Email: y_el_nahhal@hotmail.com
}

How to cite this paper: El-Nahhal, Y. (2017) A New Field Protocol for Determination of Forest Structure, Biodiversity and Heath Status by Means of GPS Tools: A Case Study from Gaza Forest. Open Journal of Ecology, 7, 69-83.

http://dx.doi.org/10.4236/oje.2017.71006

Received: December 18, 2016

Accepted: January 22, 2017

Published: January 25, 2017

Copyright $\odot 2017$ by author and Scientific Research Publishing Inc. This work is licensed under the Creative Commons Attribution International License (CC BY 4.0).

http://creativecommons.org/licenses/by/4.0/

\begin{abstract}
This article describes the application of GPS, image processing analysis and statistical tools for determination of forest structure and biodiversity. The idea is based on determination of forest area using GPS tools, then taking representative plots "samples" about $5 \%-10 \%$ of the forest and counting the tree species in each plot (sample). This process enables the estimation of species population in each plot. The sum of all species population enables the calculation of relative density of each species. Multiplying species population with plot number of the forest enables the calculations of total species population in the forest. Calculating the relative density enables the determination of dominant, co-dominant, suppressed and flour structure of the forest. To determine the age of the forest, we apply our method on determining the diameter of trees and grouping them to four groups, this enables the estimation of dominant age within single species. From these data, we can estimate the age of the forest. This field protocol is easy and applicable and provides good results in estimating structure, age and biodiversity in the forest.
\end{abstract}

\section{Keywords}

Forest, Tree Counts, Tree Age, Biodiversity, Health Status, Field Protocol

\section{Introduction}

Forest and urban trees are of great importance for the environmental quality. It is well known that forests, urban trees and grass lands play critical roles in providing oxygen to the population and reduce carbon dioxide accumulation, maintaining high quality of clean air. Moreover, forests play critical roles in wa- 
ter quality, it is documented that forest streams and groundwater is of good quality compared to water from other land uses [1]-[7]. Forest ecology is an imported element in the ecosystem in Palestine. The population has special interests in forest and agricultural areas. Nevertheless, forest area in West Bank, Jerusalem and Gaza Strip decreased from $320 \mathrm{~km}^{2}$ in 1970 to $100 \mathrm{~km}^{2}$ in 2008 [8]. However, Ministry of Agriculture took initiative steps to protect these vulnerable areas through developing forest protecting act. Due to this initiative, the protected natural area reached to $60 \mathrm{Km}^{2}$. Moreover, further initiative was taken for greening the urban areas through planting forest trees in the main and sub-main roads. So far, there is a growing need for forest protection, development and management in Palestine. Moreover, residues of forest leaves and woods can friendly be converted to charcoal [9]. Urban trees and forest have critical role in reducing air or noise pollution, decreasing soil erosion and improving water quality. Moreover, they provide habitat for wildlife and become recreation areas for the local population. So far atmospheric pollution and human activities exposing urban trees and forest with pests or disease infestation result in reduction of tree growth. Sustainable management of forests and urban trees maintain high environmental quality and healthy forest. So far poor management of forests and urban trees may lead to losing tree population, diversity, health status and productivity. Tree population, age and biodiversity are important elements in the forest that determine its productivity growth, and health status [10]. It is well known in the literature that forest structure is categorized into four groups such as canopy trees, dominant trees, co-dominant trees, intermediate trees and suppressed trees.

Moreover, forest and urban areas may be exposed to a negative impact such as dumping chemical wastes and/or waste water [11] [12], overuse of wood trees, acid rain and so on. Several attempts have been made to measuring negative impact on forest; these include life cycle assessment, material flow analysis, environmental management accounting and phytotoxicity due to pesticides application [13]-[18]. In addition forest degradation in Palestine may occur due to population increase and urbanization of agricultural land whereas in other countries forest degradation may occur due to anthropogenic activities [19] [20], or intensification of agriculture and expansion of mixed-crop livestock systems into former grazing land and other natural areas [21] [22] [23]. These processes may lead to a decline in the ecological stability of these systems [24] [25]. Management of forests requires background information on the forest structure, tree distribution, abundance, relative density and biodiversity. However, several attempts [26]-[32] have been made to estimate population, biodiversity, productivity and total biomass of many forests around the globe. These studies consumed longer time, large efforts and the estimation did not cover many properties of the forest. This study describes a field statistical protocol that can easy be applied for accurately determining forest structure, biodiversity, population and health status. The idea stands behind the field protocol based on the distribution of randomized block design in the forest, selection of surveying 
plots and testing the protocol in different locations.

\section{Materials and Methods}

\subsection{Description of the Study Site}

Gaza Strip is a semi-arid zone of southern part of Palestine with a total area of $365 \mathrm{Km}^{2}$. About 2 million inhabitants live and work. Agricultural activity is the main activity of large portion of population. Distribution of lands are 166, 126, 45 and $28 \mathrm{Km}^{2}$ for agricultural land, urban areas, destroyed land and forest area respectively [33], recent report (Ministry of Agriculture, [34] figured out the agricultural land as vegetables area 81.52, crop land 37.01, and fruit area 79.7 $\mathrm{Km}^{2}$. Average rain fall ranged from $280-480 \mathrm{~mm}$ /year. Temperature ranged between $13.4^{\circ} \mathrm{C}$ in January to $25.5^{\circ} \mathrm{C}$ in July.

\subsection{Estimation of the Total Area of the Forest}

This step was based on determining four points acting as corners of the forest and determining the distances among them using GPS tools. This enables exact determination of forest area especially in the large-scale issues. To make it easy for a non-specialized reader, we propose a forest with an area of $10^{6} \mathrm{~m}^{2}$ full of different trees. Using GPS tools and Google Earth, we theoretically subdivided the area of the forest to 100 plots (surveying plots) having nearly the same area, then taking a representative sample of $10 \%-15 \%$ of the plots for tree counts, tree diameter determination, health status of trees and biodiversity determination.

\subsection{Random Selection of Representative Surveying Plots}

About 10 - 15 plots can be selected randomly based on complete randomized block design. After selection, using GPS tools the actual position of theses plots can be identified and marked for surveying process.

\subsection{Determination of Tree Population, Relative Density, Age, Health Status and Biodiversity}

According to previous development of bioassay techniques [35] [36] and recent development [37] [38], we surveyed the trees in each of the targeted plots (surveying plots). This step enables determination of tree types, population of each type $(\mathrm{P})$ and relative density $(\mathrm{RD})$.

\subsection{Determination of Average and Standard Deviation of Each Tree Type in All Plots Using Equation (1)}

$$
\text { Average of tree type } 1=\frac{\sum(T 1+\cdots+T n)}{n}
$$

where $T 1+\cdots+T n$ represent tree counts of a tree type 1 in surveying plot 1 up to plot $\mathrm{n}$, respectively.

Similarly, average of tree type 2, type 3 , type 4 and type $\mathrm{n}$ were calculated. Then the standard deviation of tree a type 1, type 2, type 3 and type $n$ were cal- 
culated according to the standard statistical method using Excel software.

\subsection{Determination of Correction Factors}

If the value of the standard deviation is too high, this indicates a not homogeneous distribution of the trees in the surveying plots. In this case the extreme value of the tree count should be removed. This makes the values more homogenized than before. This correction may be done for one plot. Then it is necessary to add minus one wherever making the final calculation.

\subsection{Determination of Relative Density (RD)}

Based on recent development [39] [40], the above calculations provide values of average of each tree type. Then we count the sum of average of all tree types. The produced number is used to estimate the relative density of each type using Equation (2):

$$
\text { RD of a tree type }=\frac{\text { average of a tree type }}{\text { sum of all averages }}
$$

according to this calculation the sum of $\mathrm{RD}$ of all tree types is equal 1 . This calculation enables the determination of biodiversity of trees in the forest. The highest $\mathrm{RD}$ value of a tree indicates the dominant type, co-dominant, suppressed, and forest flour.

\subsection{Determination of Total Tree Population (P) in the Forest}

Population of a tree type 1 can be calculated according to Equation (3)

$$
P 1=\text { average of a tree type } 1 * Z
$$

where $Z$ is the total number of plots in the forest, and consequently the population of all tree types are determined. In case of a correction factor was made to any tree type during the calculation process to get homogenized average with low value of standard deviation, Equation (4) is used instead of Equation (3) to estimate the corrected population of a tree type

$$
C P 1=\text { average of a tree type } 1 *(Z-1) \text {. }
$$

The sum of tree population in the forest equals to the sum of all tree types according to Equation (5)

$$
P n=P 1+P 2+P 3+\cdots+P n
$$

in case of a correction factor was made during the calculation process, the corrected population of a tree type $\left({ }^{\star} \mathrm{P} 1\right)$ is replacing the old value.

\subsection{Determination of Forest Tree Age}

The highest $\mathrm{RD}$ value of a tree type indicates the dominant tree population, whereas the lowest $\mathrm{RD}$ value indicates the forest floor. However, focusing on the highest $\mathrm{RD}$ value in the forest may enable the determination of the tree diameter and consequently tree age as shown in Figure 1. In this procedure we consider the surveying plots and focus only on one tree type and determining the tree 


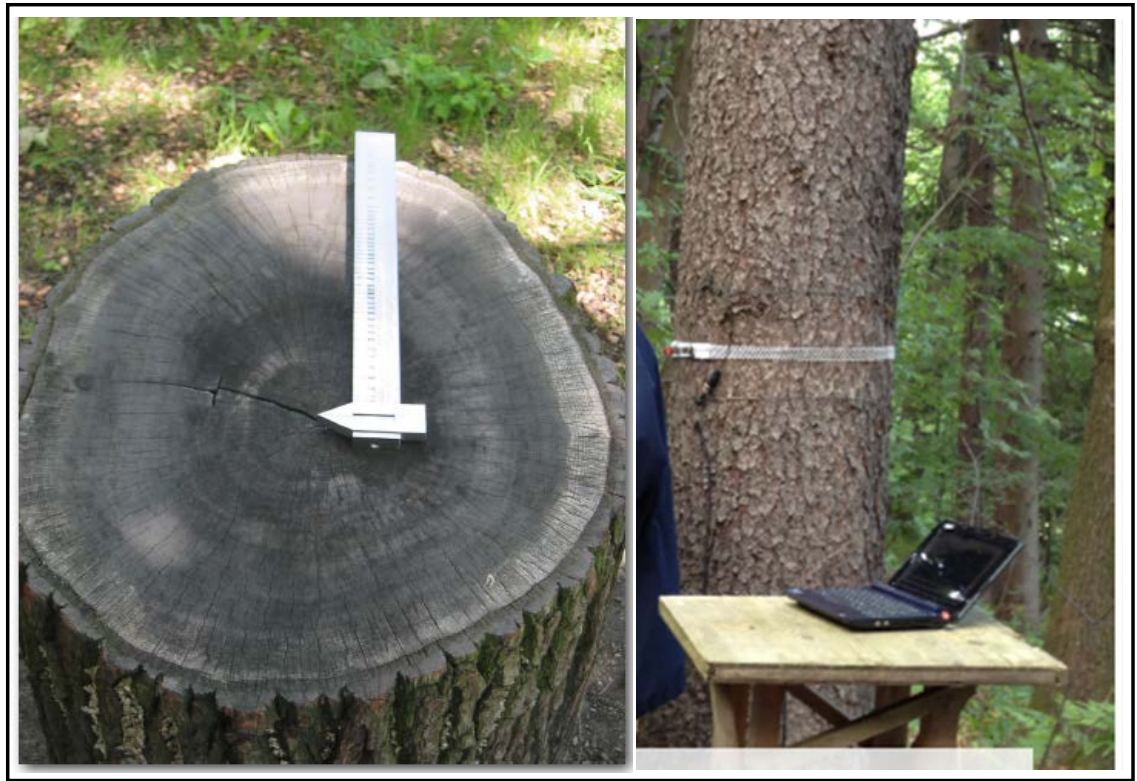

Figure 1. Measuring tree diameter to characterize tree age (adapted from Ref. [41] [42] [43]).

diameter using the following equation

$$
A=\pi r
$$

where $A$ is the tree circle and $\mathrm{r}$ is the tree diameter. This step enables collections of tree population diameter as in Figure 1. Then these data needs cleaning and grouping as reported in Table 3.

This grouping may be valid and could be applied for other trees. In some case modification of the groups is necessary to be able to survey all types. Based on the calculation shown above for a tree population type, it would be possible to survey the diameters of the corresponding tree type in each surveying plot then summarizing the groups and calculate the average and standard deviation of each group. If a correction factor is necessary to be made then, it can be considered during the calculation. Finding the relative density enables detecting the dominant tree diameter in the tree type consequently knowing the age. This may enable scaling the group age of the trees.

\subsection{Determination of Health Status of Forest Tree}

In the surveying plots we survey only the attached trees by insects or fungi. Then following the procedure described above we estimate the total attached trees. Then we calculated the relative density of the attached trees $(R D A T)$ as on Equation (6).

$$
R D A T=\frac{\text { sum of attected tree }}{\text { Total tree population }} \text {. }
$$

If the value is below 0.05 then the forest is healthy, if above, initiative steps may be taken to protect the forest such as removal of attached trees, using natural enemies and/or integrated pest management. RDAT may also be referred as critical limit of pest attach [44]. 


\section{Results}

The presented results in Table 1 clearly show the application of the statistical method for determination the $\mathrm{RD}$ and population $(\mathrm{P})$ of each tree type assuming nearly homogenized distribution of each tree type in the forest.

Tree type 1 had the highest RD among all followed by tree type 4 , tree type 2 , tree type 5. It can be concluded that tree type 1 is the dominant type in the forest followed by tree type 5 , co-dominant type, type 3 is suppressed group whereas group 3 and 6 can be considered the forest floor. The data in Table 2 clearly show theoretical calculation of unhomogenized distribution of tree types (type 2, 3 and 6) as reported in bold in the table. These values were removed from calculating the average and $\mathrm{RD}$. Accordingly revised average and $\mathrm{RD}$ values were obtained. Consequently, the values of corrected average (CA), corrected relative density (CRD) and corrected population (CP) are higher than original ones (A, $\mathrm{RD}^{0}$ and $\left.\mathrm{P}^{0}\right)$. These data indicate the validation of the applied method for determination of forest structure and biodiversity. These results agree with recent [22]-[27] and previous reports [44] [45] who used weed index to survey weed population under field conditions.

\subsection{Determination of Forest Tree Age}

The data in Table 3 provide possible calculation and diameter grouping of one tree type. According to the variation of collected field results, three-five groups may be generated and applied. It may be possible to reduce them to lower or higher number of groups based on the collected field data.

Table 1. Homogenized theoretical calculation of a forest population.

\begin{tabular}{ccccccc}
\hline Tree & Plot 1 & Plot 2 & Plot $\mathrm{n}$ & Average & $\mathrm{RD}$ & Population $(\mathrm{P})$ \\
\hline Type 1 & 29 & 24 & 26 & 26 & 0.26 & 2600 \\
Type 2 & 16 & 18 & 20 & 18 & 0.18 & 1800 \\
Type 3 & 15 & 12 & 11 & 13 & 0.13 & 1300 \\
Type 4 & 29 & 25 & 22 & 25 & 0.25 & 2500 \\
Type 5 & 14 & 12 & 15 & 14 & 0.14 & 1400 \\
Type 6 & 3 & 4 & 7 & 5 & 0.05 & 500 \\
Total & & & & 101 & 1.00 & 10,100 \\
\hline
\end{tabular}

Table 2. Calculation based on corrected average (CA).

\begin{tabular}{cccccccccccc}
\hline Tree & Plot 1 & Plot 2 & Plot 3 & Plot $\mathrm{n}$ & $\mathrm{A}$ & $\mathrm{StDev}$ & $\mathrm{CA}$ & $\mathrm{CRD}$ & $\mathrm{RD}^{0}$ & $\mathrm{CP}$ & $\mathrm{P}^{0}$ \\
\hline Type1 & 29 & 24 & 40 & 26 & 30 & 7 & 30 & 0.27 & 0.29 & 3000 & 3000 \\
Type 2 & 16 & 18 & 20 & 7 & 15 & 2 & 18 & 0.16 & 0.15 & 1782 & 1500 \\
Type 3 & 15 & 12 & 11 & 5 & 11 & 2 & 13 & 0.12 & 0.1 & 1287 & 1100 \\
Type 4 & 29 & 25 & 33 & 22 & 27 & 5 & 27 & 0.25 & 0.26 & 2700 & 2700 \\
Type 5 & 14 & 12 & 19 & 15 & 15 & 3 & 15 & 0.14 & 0.14 & 1500 & 1500 \\
Type 6 & 7 & 4 & 9 & 3 & 6 & 3 & 7 & 0.06 & 0.06 & 693 & 600 \\
& & & & & 104 & & 109 & 1 & 1 & 10962 & 10400 \\
\hline
\end{tabular}

$\mathrm{A}=$ original average, $\mathrm{CA}=$ corrected average, $\mathrm{CRD}=$ corrected relative density, $\mathrm{RD}^{\circ}=$ original relative density, $\mathrm{CP}=$ corrected population, $\mathrm{P}^{\circ}=$ original population. 
Table 3. Tree type 1 diameter grouping in the forest.

\begin{tabular}{ccccccc}
\hline Diameter group & Plot 1 & Plot 2 & Plot n & A & RD & Population \\
\hline Group 1 ( 0.3 - 0.6 m) & 9 & 8 & 10 & 9 & 0.3 & 900 \\
Group 2 (0.61 - 1.0 m) & 8 & 6 & 7 & 7 & 0.23 & 700 \\
Group 3 (1.01 - 1.5 m) & 4 & 6 & 5 & 5 & 0.17 & 500 \\
Group 4 (1.51 - 2.0 m) & 5 & 4 & 6 & 5 & 0.17 & 500 \\
Group 5 (>2.01 m) & 3 & 4 & 5 & 4 & 0.13 & 400 \\
Total & & & & & 1 & 3000 \\
\hline
\end{tabular}

$\mathrm{A}=$ average, $\mathrm{RD}=$ relative density.

\subsection{Determination of Age of the Dominant Trees in the Forest}

Based on the data presented in Table 3, it would be possible to collect a sample of each type of the trees and making a stem cut as in Figure 1 to know the exact stem circle which indicates number of tree age in years. Moreover, it would be possible use the published data base to know the average diameter of each age group of the trees.

\subsection{Determination of Health Status of the Forest}

Forest trees may be attacked by insects and fungi and a serious damage may occur to the trees. Application of the model mentioned above enables surveying the attacked trees. Then it would be possible to estimate the relative density of attacked trees (RDAT) from Equation (6). If the calculated value is equal or less than 0.05 the forest is healthy, if above, then the forest is not healthy. Moreover, the $R D A T$ can be referred to as critical limit of pest attack.

Based on the data presented in Table 4, it would be possible estimate the attacked trees and calculate the RDAT.

\section{Discussion}

In this paper we provided an easy applied field protocol for estimating tree abundance, population, relative density, biodiversity and health status. The protocol based on theoretical and practical field survey. The strong point of the protocol is that it is flexible in determining the average and the standard deviation and make homogenization in case of high variation in the survey plots as in $\mathrm{Ta}$ ble 1 and Table 2. Moreover, the protocol enabled corrections to avoid extreme values to be in the actual mode of estimation. In addition, the protocol enabled the determination of biodiversity of forest at end point and its health status (Table 4). The weak point of the protocol is that it cannot be applied for forest was exposed to disasters or ecological imbalance. Furthermore, the paper provided several possibilities of using the protocol in estimating the tree abundance, biodiversity, total population, and health status.

In addition, the presented field protocol revealed accurate estimation of trees after inclusion of corrections (Table 2) and shows that removal of extreme values for calculation provides accurate and actual population of tree type in the forest. Furthermore, the field protocol was successfully tested on weed estimation 
Table 4. Tree type 1 diameter grouping in the forest.

\begin{tabular}{ccccccc}
\hline Pest type & Plot 1 & Plot 2 & Plot n & Average & RDAT & $\begin{array}{c}\text { Sum of } \\
\text { attached trees }\end{array}$ \\
\hline Insect & 6 & 9 & 16 & 10.33 & 9.43 & 1033.33 \\
Fungi & 8 & 12 & 4 & 8 & 7.30 & 800 \\
\hline
\end{tabular}

in Gaza for a small agricultural area $\left(1 \mathrm{Km}^{2}\right)$ data not shown. In this test, two weed populations (Cyperus rotundus and Setaria viridis) were estimated by the model and by manual sorting method [11] [25] [37] [40] [44]. There has been about $11 \%$ difference between the two methods of estimation. A traceable investigation of errors found that Cyperus rotundus weed was counted as Setaria viridis in many cases due to similarity of plant feature (see Figure 2).

Correcting this minor mistake in the test, reduced the difference from $11 \%$ to $7 \%$ between the two method of estimation. This test validates our field protocol for estimating forest tree population and relative density. More support to our field protocol comes from estimating urban trees in two main roads in Gaza Strip (Salah Eddin Street $45 \mathrm{~km}$ long; Omer Al-Mukhtar Street $5 \mathrm{~km}$ long). The protocol found $17 \%$ difference between actual number in trees in the data base of Municipality of Gaza and those existing in the street. Traceability test of the street found about $5 \mathrm{~km}$ long of the street free from trees due to road construction and repair. Application of the correction in our field protocol (Table 2) reduced the difference from $17 \%$ to $6 \%$, confirming the accuracy of our field protocol. The test with Omer Al-Mukhtar street shows 7\% difference which is in the acceptable range of field difference [46] [47]. Further support to our field protocol came from testing the field protocol in a protected area (Wadi Gaza) (Figure 3 ) and found differences less that $5 \%$ in the planted trees such as fruit trees (olive trees, grapes, palm) but we found 19\% differences in weed population in the Wadi and in urban trees (Figure 4). Traceable investigation found differences in soil types which was stand behind the differences in weed population [48] [49]. Additional support to the protocol comes for practical testing the productivity in agricultural land cultivated with cabbage (Figure 5). So far, the presented results clearly show practical application of field protocol for determining forest tree population relative density and biodiversity. These data agree with previous reports [46] [47] who used weed index to estimate the abundance of weeds in herbicides treated field plots. Further support to our method come from Ref. [48] and Ref. [49] who estimated the field phyto-toxicity of pesticides using plant biomass and heights. Moreover, several authors [50] [51] [52] [53] [54] successfully used the statistical methods to determine distribution and abundance of different pollutants in all components of ecosystem. Further supports to our method can be obtained from different studies [55]-[60] who used statistical methods to differentiate the growth of cyanobacterial mats under stress factors. The weakness of the field protocol is that it can produce large differences in estimating weeds or planted trees in urban areas, or in fields with different soil type or in area with different climate conditions such as a coastal zone area 
Cyperus rotundus

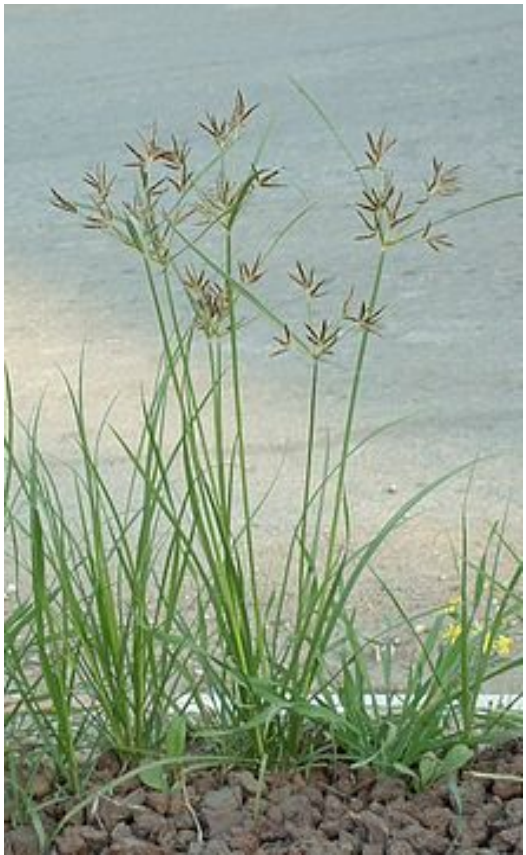

Setaria viridis

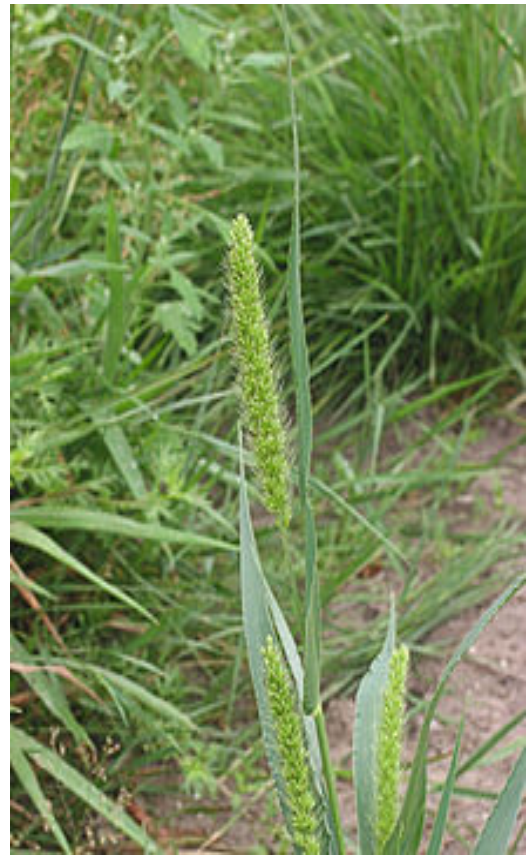

Figure 2. Photos of weeds used to test the field protocol (photos adopted from Wikipedia).
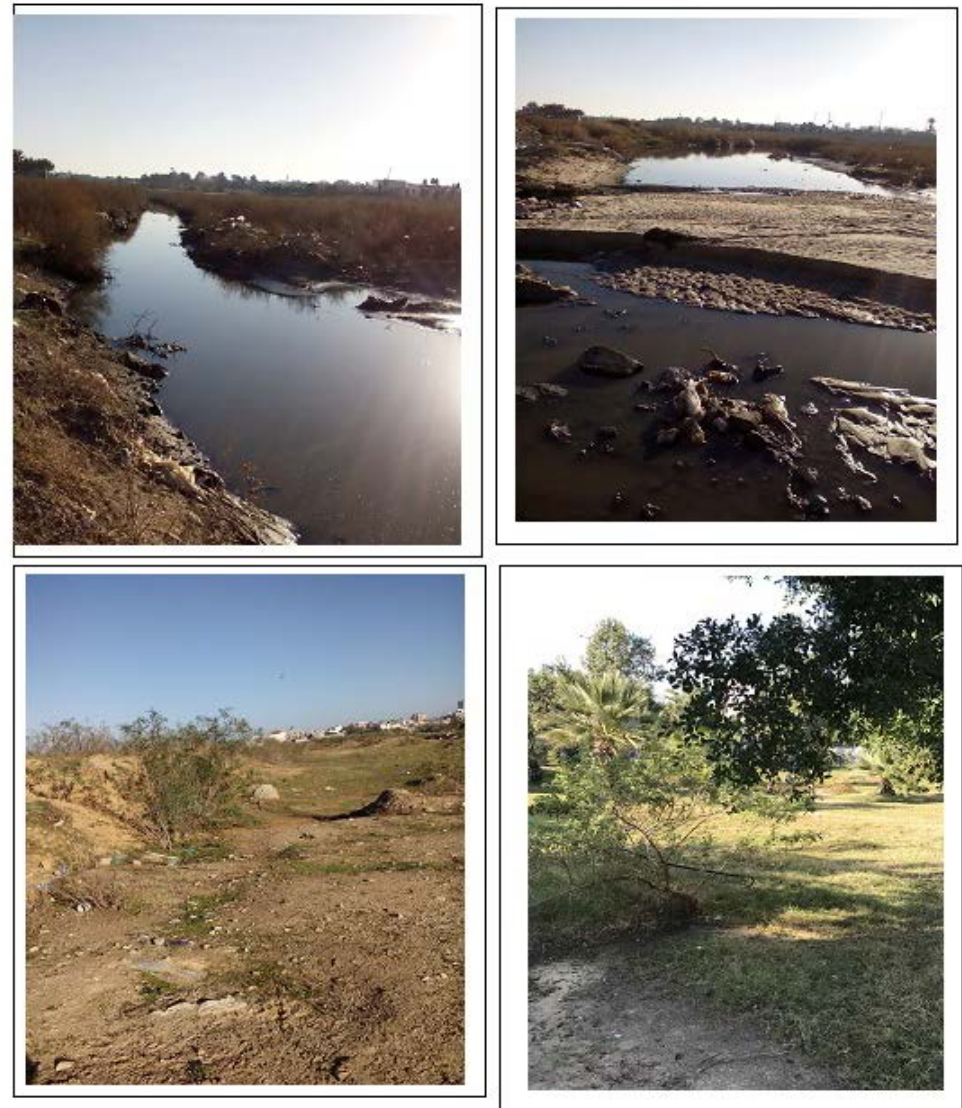

Figure 3. Testing the field protocol in estimation of trees and weed in different sections of Widi Gaza. 


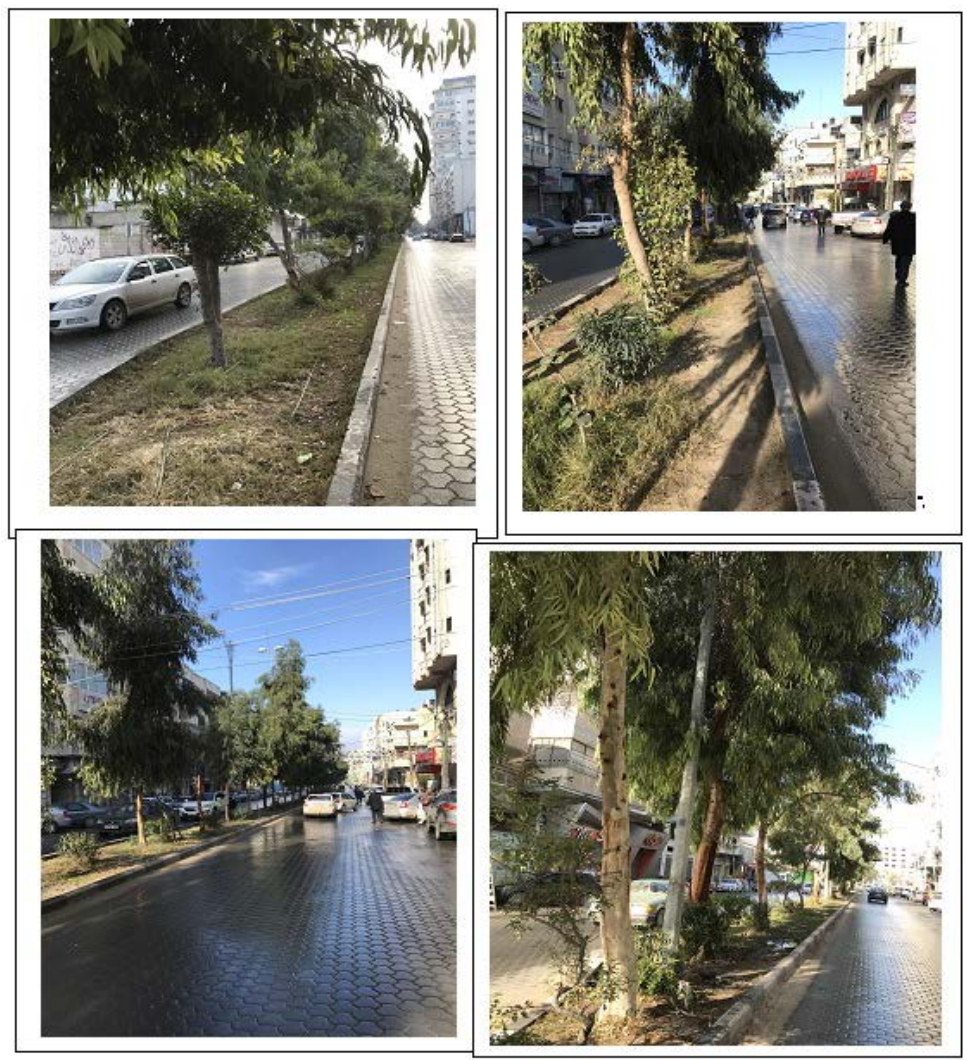

Figure 4. Testing the field protocol in estimation of urban tree population and biodiversity (photos adopted from different locations).

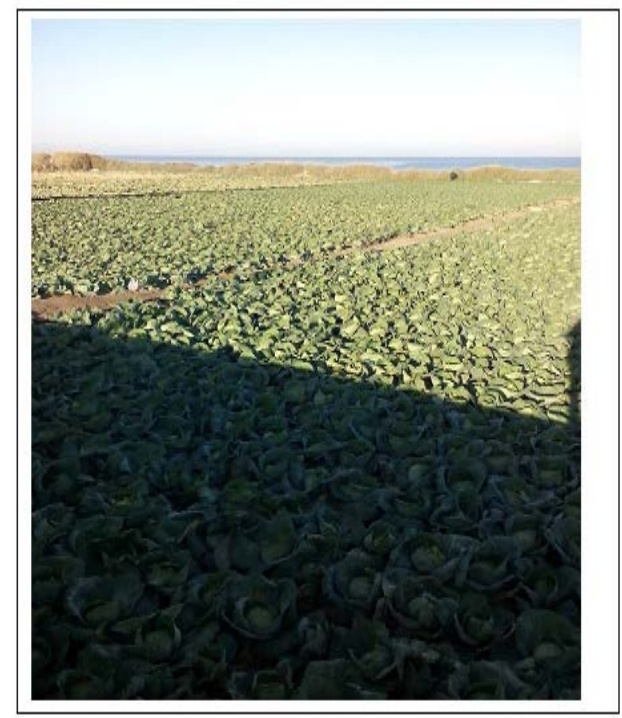

Figure 5. Testing the field protocol in estimation of agricultural productivity in cabbage field.

and desert land. For instance, if we estimated the population of salt plants ( $\mathrm{Me}$ sembryanthemum acinaciforme) in the coastal area, the abundance of the salt plant will be very close to the sea shore and become very rare far away from the shore due to the decline of salt concentration. Moreover, estimating the popula- 
tion of desert plants in a coastal area will not be homogenized due to growth conditions. Under these conditions, the field protocol may be validated if the area can be subdivided to a small scale and deal with each scale as a separate unit in applying the protocol.

\section{Conclusion}

The field protocol provides accurate results that can easily match the data obtained by manual investigation. The protocol can easily be applied for multi scale environment. It is also valid for large scale forests where trees are normally grown without any man-made interference and not exposed to fire or a disaster. So far, the protocol can easily be applied for estimating productivity, health status and maturity of fruits of agricultural lands. Moreover, it is a useful tool in investigating percentage of seed germination in large scale agricultural land, testing herbicidal activity and maturity of fruits in large field scale, to evaluate sugar production in citrus fruit. The weak point of protocol is that it may not provide accurate results in a small scale forest where trees are exposed to grazing of animal infestation. The method can save time and efforts and cost of evaluation.

\section{Acknowledgements}

Special thanks to the Alexander von Humboldt foundation for a Research Fellowship at Leipzig University and BAM institute Germany 2016. I would also like to thank my students at faculty of science for helping me during the field work.

\section{Ethical Statement}

This study was not funded by any organization.

\section{Conflict of Interest}

Author declares that he has no conflict of interest.

The study complies with the international ethics issues.

\section{References}

[1] Callesen, I., Raulund-Rasmussen, K., Gundersen, P. and Stryhn, H. (1999) Nitrate Concentrations in Soil Solutions below Danish Forests. Forest Ecology and Management, 114, 71-82. https://doi.org/10.1016/S0378-1127(98)00382-X

[2] Thornton, K.W., Holbrook, S.P., Stolte, K.L. and Landy, R.B. (2000) Effects of Forest Management Practices on Mid-Atlantic Streams. Environ. Monitoring and Assessment, 63, 31-41. https://doi.org/10.1023/A:1006449131282

[3] El-Nahhal, Y. (2006) Contamination of Groundwater with Heavy Metals in Gaza. Proceedings of the Tenth International Water Technology Conference, Alexandria, Egypt, 23-25 March 2006, 1139-1150.

[4] El-Nahhal, Y. and Safi, J. (2008) Removal of Pesticide Residues from Water by Organo-Bentonites. Proceedings of the Twelfth International Water Technology Conference, Alexandria, Egypt, 27-30 March 2008, 1711-1724. 
[5] El-Nahhal, I., Al-Najar, H. and El-Nahhal, Y. (2014) Physicochemical Properties of Sewage Sludge from Gaza. International Journal of Geosciences, 5, 586-594. https://doi.org/10.4236/ijg.2014.56053

[6] Al-Arifi, S.N., Al-Agha, R.M. and El-Nahhal, Z.Y. (2013) Environmental Impact of Landfill on Groundwater, South East of Riyadh, Saudi Arabia. Journal of Natural Science Research, 3, 222-242.

[7] Al-Arifi, S.N., Al-Agha, R.M. and El-Nahhal, Z.Y. (2013) Hydrogeology and Water Quality of Umm Alradhma Aquifer, Eastern Saudi Arabia. Journal of Environment and Earth Science, 3, 118-127.

[8] Hammad, B. (2013) Forests in Palestine Ministry of Agriculture. Proceedings of D. G. of Forests and Rangeland, Vienna, 14-18 February 2013, 1-31.

[9] Telbani, M. (2016) Environmental Production of Charcoal from Plant Leaves. M.Sc Thesis, The Islamic University-Gaza, Palestine.

[10] Chen, J.M., Zhou, W.W., Poyarkov Jr., N.A., Stuart, B.L., Brown, R.M., Lathrop, A., Wang, Y.Y., Yuan, Z.Y., Jiang, K., Hou, M., Che, H.M., Suwannapoom, C., Ngoc Nguyen, S., Van Duong, T., Papenfuss, T.J., Murphy, R.W., Zhang, Y.P. and Che, J. (2016) A Novel Multilocus Phylogenetic Estimation Reveals Unrecognized Diversity in Asian Horned Toads, Genus Megophrys sensu Lato (Anura: Megophryidae). Molecular Phylogenetics and Evolution, 106, 28-43.

[11] El-Nahhal, Y., Safi, M., Tubail, K. and Safi, J. (2013) Effect of Treated Wastewater Irrigation on Plant Growth and Soil Properties in Gaza Strip Palestine. American Journal of Plant Science, 4, 1736-1743. https://doi.org/10.4236/ajps.2013.49213

[12] Kaschl, A., El-Nahhal, Y., Abu Mourad, T., Tubail, K., Safi, J., Hadar, Y., Chen, Y. and Roemheld, V. (1998) Long Term Field Experiment to Examine the Agricultural Application of Municipal Solid Waste Compost in Gaza Strip. Proceedings of Verb and Deutscher Landwirtschaftlicher Untersuchungsund Forschungsanstalten, Eiladung, 17-18 September 1998, 251-254.

[13] El-Nahhal, Y., Nir, S., Serban, S., Rabinowitz, O. and Rubin, B. (2001) Organoclay Formulation of Acetochlor for Reduced Movement in Soil. Journal of Agricultural and Food Chemistry, 49, 5464-5371. https://doi.org/10.1021/jf010561p

[14] El-Nahhal, Y., Undabeytia, T., Polubesova, T., Golda Mishael, Y., Nir, S. and Rubin, B. (2001) Organo-Clay Formulations of Pesticides: Reduced Leaching and Photodegradation. Applied Clay Science, 18, 309-326. https://doi.org/10.1016/S0169-1317(01)00028-X

[15] Kauffman, J.B. and Donato, D.C. (2012) Protocols for the Measurement, Monitoring and Reporting of Structure, Biomass and Carbon Stocks in Mangrove Forests. Working Paper 86, CIFOR, Bogor.

[16] ISO (2011) ISO 14051:2011. Environmental Management-Material Flow Cost Accounting-General Framework. ISO, Geneva.

[17] Kokubu, K. and Kitada, H. (2015) Material Flow Cost Accounting and Existing Management Perspectives. Journal of Cleaner Production, 108, 1279-1288. https://doi.org/10.1016/j.jclepro.2014.08.037

[18] Papaspyropoulos, K.G., Karamanolis, D., Sokos, C.K. and Birtsas, P.K. (2016) Enhancing Sustainability in Forestry Using Material Flow Cost Accounting. Open Journal of Forestry, 6, 324-336. https://doi.org/10.4236/ojf.2016.65026

[19] GoK (2009) Rehabilitation of the Mau Forest Ecosystem, Project Concept by the Interim Coordinating Secretariat. Office of the Prime Minister.

[20] Mati, B.M., Mutie, S., Gadain, H., Home, P. and Mtalo, F. (2008) Impacts of LandUse/Cover Changes on the Hydrology of the Transboundary Mara River, Kenya/ Tanzania. Lakes and Reservoirs. Research and Management, 13, 169-177. 
https://doi.org/10.1111/j.1440-1770.2008.00367.x

[21] Olson, J.M. and Maitima, J.M. (2006) Sustainable Intensification of Mixed CropLivestock Systems, Land Use Change Impacts and Dynamics (Lucid). International Livestock Research Institute, Nairobi.

[22] Enanga, M., Shivoga, W., Maina-Gichaba, C. and Creed, F. (2011) Observing Changes in Riparian Buffer Strip Soil Properties Related to Land Use Activities in River Njoro Watershed, Kenya. Water and Air Soil Pollution, 218, 587-601. https://doi.org/10.1007/s11270-010-0670-Z

[23] Njue, N., Koech, E., Hitimana, J. and Sirmah, P. (2016) Influence of Land Use Activities on Riparian Vegetation, Soil and Water Quality: An Indicator of Biodiversity Loss, South West Mau Forest, Kenya. Open Journal of Forestry, 6, 373-385. https://doi.org/10.4236/ojf.2016.65030

[24] Matano, A.S., Kanangire, C.K., Anyona, D.N., Abuom, P.O., Gelder, F.B., Dida, G.O., Owour, P.O. and Ofulla, A.V.O. (2015) Effects of Land Use Change Degradation Reflected by Soil Properties along Mara River, Kenya and Tanzania. Open Journal of Soil Science, 5, 20-38. https://doi.org/10.4236/ojss.2015.51003

[25] El-Nahhal, Y. and Hamdona, N. (2016) Adsorption, Leaching and Phytotoxicity of Some Herbicides as Single and Mixtures to Some Crops. Journal of the Association of Arab Universities for Basic and Applied Science, in Press. https://doi.org/10.1016/j.jaubas.2016.01.001

[26] Wang, Y.Y., Yuan, Z.Y., Jiang, K., Hou, M., Chen, H.M., Suwannapoom, C., Ngoc Nguyen, S., Van Duong, T., Papenfuss, T.J., Murphy, R.W., Zhang, Y.P. and Che, J. (2016) A Novel Multilocus Phylogenetic Estimation Reveals Unrecognized Diversity in Asian Horned Toads, Genus Megophrys sensu lato (Anura: Megophryidae). Molecular Phylogenetics and Evolution, 106, 28-43.

[27] Khan, M.N., Hijbeek, R., Berger, U., Koedam, N., Grueters, U., Islam, S.M., Hasan, M.A. and Dahdouh-Guebas, F. (2016) An Evaluation of the Plant Density Estimator the Point-Centred Quarter Method (PCQM) Using Monte Carlo Simulation. PLoS ONE, 11, e0157985. https://doi.org/10.1371/journal.pone.0157985

[28] Duarte, G.T., Ribeiro, M.C. and Paglia, A.P. (2016) Ecosystem Services Modeling as a Tool for Defining Priority Areas for Conservation. PLoS ONE, 11, e0154573. https://doi.org/10.1371/journal.pone.0154573

[29] Kushwaha, S.P., Nandy, S. and Gupta, M. (2014) Growing Stock and Woody Biomass Assessment in Asola-Bhatti Wildlife Sanctuary, Delhi, India. Environmental Monitoring and Assessment, 186, 5911-5920.

https://doi.org/10.1007/s10661-014-3828-0

[30] Choi, Y.J., Klosterman, S.J., Kummer, V., Voglmayr, H., Shin, H.D. and Thines, M. (2015) Multi-Locus Tree and Species Tree Approaches toward Resolving a Complex Clade of Downy Mildews (Straminipila, Oomycota), Including Pathogens of Beet and Spinach. Molecular Phylogenetics and Evolution, 86, 24-34.

https://doi.org/10.1016/j.ympev.2015.03.003

[31] Ureta Adrianzén, M. (2015) Aboveground Biomass Input of Myristicaceae Tree Species in the Amazonian Forest in Peru. Revista de Biología Tropical, 63, 263-273. https://doi.org/10.15517/rbt.v63i1.14254

[32] Slik, J.W., Arroyo-Rodríguez, V., Aiba, S., Alvarez-Loayza, P., Alves, L.F., Ashton, P., et al. (2015) An Estimate of the Number of Tropical Tree Species. Proceedings of the National Academy of Sciences of the United States of America, 112, 7472-7477. https://doi.org/10.1073/pnas.1423147112

[33] Abu Aayesh, M., Al-Jabbarin, B., Al-Abadi, H. and Qufishah, W. (2007) Scanning and Classification of Forest Trees in Palesite. Arab Organization for Agricultural 
Development, 1-194.

[34] Ministry of Agriculture, PNA (2016) Annual Report. Gaza Strip, Palestine.

[35] El-Nahhal, Y. (2003) Persistence, Mobility, Efficacy and Safety of Chloroacetanilide Herbicide Formulation under Field Conditions. Environmental Pollution, 124, 33 38. https://doi.org/10.1016/S0269-7491(02)00431-1

[36] El-Nahhal, Y. (2003) Adsorptive Behavior of Acetochlor on Organoclay Complexes. Bulletin of Environmental Contamination and Toxicology, 70, 1104-1111. https://doi.org/10.1007/s00128-003-0096-Z

[37] El-Nahhal, Y., Awad, Y. and Safi, J. (2013) Bioremediation of Acetochlor in Soil and Water Systems by Cyanobacterial Mat. International Journal of Geosciences, 4, 880 890. https://doi.org/10.4236/ijg.2013.45082

[38] El-Nahhal, Y., Wheidi, B. and El-Kurdi, S. (2016) Development of Ecologically Acceptable Chlorpyrifos Formulation for Effective and Safe Application. Journal of Encapsulation and Adsorption Sciences, 6, 91-108. https://doi.org/10.4236/jeas.2016.63008

[39] El-Nahhal, Y., EL-dahdouh, N., Hamdona, N. and Alshanti, A. (2016) Toxicological Data of Some Antibiotics and Pesticides to Fish, Mosquitoes, Cyanobacterial Mats and to Plants. Data in Brief, 6, 871-880. https://doi.org/10.1016/j.dib.2016.01.051

[40] El-Nahhal, Y. and Hamdona, N. (2015) Phytotoxicity of Alachlor, Bromacil and Diuron as Single or Mixed Herbicides Applied to Wheat, Melon, and Molokhia. SpringerPlus, 4, 364. https://doi.org/10.1186/s40064-015-1148-7

[41] Lafortezza, R., Davies, C., Sanesi, G. and Konijnendijk, C. (2013) Green Infrastructure as a Tool to Support Spatial Planning in European Urban Regions. iForestBiogeosciences and Foresty, 6, 102-108. https://doi.org/10.3832/ifor0723-006

[42] Millennium Ecosystem Assessment (2005) Ecosystems and Human Well Being: Synthesis. Island Press, Washington DC.

[43] Urban Forest Monitoring (2016) Chapter 3. 188-211. http://www.emonfur.eu

[44] El-Nahhal, Y., Nir, S., Polubesova, T., Margulies, L. and Rubin, B. (1997) OrganoClay Formulations of Alachlor: Reduced Leaching and Improved Efficacy. Weeds, 1 , 21-26.

[45] El-Nahhal, Y., Lagaly, G. and Rabinovitz, O. (2005) Organo-Clay Formulations of Acetochlor: Effect of High Salt. Journal of Agricultural and Food Chemistry, 53, 1620-1624. https://doi.org/10.1021/jf040383a

[46] El-Nahhal, Y., Nir, S., Polubesova, T., Margulies, L. and Rubin, B. (1998) Leaching, Phytotoxicity and Weed Control of New Formulations of Alachlor. Journal of Agricultural \& Food Chemistry, 46, 3305-3313. https://doi.org/10.1021/jf971062k

[47] El-Nahhal, Y., Nir, S., Polubesova, T., Margulies, L. and Rubin, B. (1999) Movement of Metolachlor in Soil: Effect of Organo-Clay Formulation. Pesticide Science, 55, 857-864. https://doi.org/10.1002/(SICI)1096-9063(199908)55:8<857::AID-PS24>3.0.CO;2-P

[48] El-Nahhal, Y., Nir, S., Serban, C., Rabinowitz, O. and Rubin B. (2000) Montmorillonite-Phenyltrimethylammounium Yields Environmentally Improved Formulations of Hydrophobic Herbicides. Journal of Agricultural and Food Chemistry, 48, 4791-4801. https://doi.org/10.1021/jf000327j

[49] El-Nahhal, Y., Nir, S., Margulies, L. and Rubin, B. (1999) Reduction of Photodegradation and Volatilization of Herbicides in Organo-Clay Formulations. Applied Clay Science, 14, 105-119.

[50] Schecter, A., Papke, O., Ryan, J., Furst, P., Isaac, J., Hrimat, N., Neiroukh, F., Safi, J., El-Nahhal, Y., Abu El-Haj, S., Avni, A., Richter, E., Chuwers, P. and Fischbein, A. 
(1997) Dioxins, Dibenzofurans and PCBs in Human Blood, Human Milk and Food from Israel, The West Bank and Gaza. Organohalogen Compounds, 33, 457-461.

[51] Schecter, A., Papke, O., Isaac, J., Hrimat, N., Neiroukh F., Safi, J. and El-Nahhal, Y. (1997) 2,3,7,8 Chlorine Substituted Dioxins and Dibenzofuran Congeners in 2,4-D, 2,4,5-T and Pentachlorophenol. Organohalogen Compounds, 32, 51-55.

[52] Abed, M.A., Safi, M.N., Köster, J., Beer, D., El-Nahhal, Y., Rullkötter, J. and Garcia-Pichel, F. (2002) Microbial Diversity of a Heavily Polluted Microbial Mat and Its Community Changes Following Degradation of Petroleum Compounds. Applied Environmental Microbiology, 68, 1674-1683. https://doi.org/10.1128/AEM.68.4.1674-1683.2002

[53] Rubin, B., El-Nahhal, Y., Nir, S. and Margulies, L. (2001) Slow Release Formulations of Pesticides. Patent No. US6,261,997 B1.

[54] Heinze, S., Chen, Y., El-Nahhal, Y., Hadar, Y., Jung, R., Safi, J., Safi, M., Tarchitzky, J. and Marschner, B. (2014) Small Scale Stratification of Microbial Activity Parameters in Mediterranean Soils under Freshwater and Treated Wastewater Irrigation. Soil Biology and Biochemistry, 70, 193-204. https://doi.org/10.1016/j.soilbio.2013.12.023

[55] Bornstein, R., Safi, J., El-Nahhal, Y., Isaac, J., Rishmawi, K., Luria, M., Mahrer, Y., Ranmar, D. and Weinroth, E. (2001) Transboundary Air-Quality Effects from Urbanization. UJSU Report to USAID-Merc.

[56] Nir, S., El-Nahhal, Y., Undabeytia, T., Rytwo, G., Polubesova, T., Mishael, Y., Rabinovitz, O. and Rubin, B. (2006) Clays and Pesticides. Developments in Clay Science, 1, 677-691. https://doi.org/10.1016/S1572-4352(05)01021-4

[57] Nir, S., Undabeytia, T., Yaron, D., El-Nahhal, Y., Polubesova, T., Serban, S., Rytwo, G., Lagaly, G. and Rubin, B. (2000) Optimization of Adsorption of Hydrophobic Herbicides on Montmorillonite Preadsorbed by Monovalent Organic Cations: Interaction between Phenyl Rings. Environmental Science and Technology, 34, 12691274. https://doi.org/10.1021/es9903781

[58] El-Nahhal, Y., Abadsa, M. and Affifi, S. (2013) Adsorption of Diuron and Linuron in Gaza Soils. American Journal of Analytical Chemistry, 4, 94-99. https://doi.org/10.4236/ajac.2013.47A013

[59] Safi, J., Awad, Y. and El-Nahhal, Y. (2014) Bioremediation of Diuron in Soil and by Cyanobacterial Mat. American Journal of Plant Sciences, 5, 1081-1089. https://doi.org/10.4236/ajps.2014.58120

[60] Safi, J., Abu Foul, N., El-Nahhal, Y. and El-Sebae, A. (2002) Monitoring of Pesticide Residues on Cucumber, Tomatoes and Strawberries in Gaza Governorates, Palestine. Nahrung, 46, 34-49. https://doi.org/10.1002/1521-3803(20020101)46:1<34::AID-FOOD34>3.0.CO;2-W 
Submit or recommend next manuscript to SCIRP and we will provide best service for you:

Accepting pre-submission inquiries through Email, Facebook, LinkedIn, Twitter, etc. A wide selection of journals (inclusive of 9 subjects, more than 200 journals)

Providing 24-hour high-quality service

User-friendly online submission system

Fair and swift peer-review system

Efficient typesetting and proofreading procedure

Display of the result of downloads and visits, as well as the number of cited articles Maximum dissemination of your research work

Submit your manuscript at: http://papersubmission.scirp.org/

Or contact oje@scirp.org 